\title{
Iron Toxicity Stress Causes Bronze Speckle, a Specific Physiological Disorder of Marigold (Tagetes erecta L.)
}

\author{
Joseph P. Albano ${ }^{1}$ and William B. Miller ${ }^{2}$ \\ Department of Horticulture, Box 340375, Clemson University, Clemson, SC 29634-0375 \\ Mary C. Halbrooks ${ }^{3}$ \\ Department of Biology and Physical Sciences, Columbia College, Columbia, SC, 296203 \\ Additional index words. Mn toxicity, metal toxicity, DTPA, EDTA, plant nutrition, bedding plants, soilless media, Tagetes patula
}

\begin{abstract}
A specific physiological disorder, bronze speckle (J.P.A.'s nomenclature), was consistently induced in 'First Lady' and 'Voyager' marigold with Fe-DTPA concentrations greater than 0.018 mM Fe-DTPA (1 ppm) applied to a soilless medium. The disorder was characterized by specific symptomology distinguished visually by speckled patterns of chlorosis and necrosis, and downward curling and cupping of leaves. The percentage of total leaf dry weight affected with symptoms generally increased with increasing Fe-DTPA treatments. Symptomatic leaf tissue had a greater Fe concentration than corresponding asymptomatic leaf tissue. Leaf Mn concentrations in symptomatic and asymptomatic tissue were similar. In 'First Lady', older leaf tissue accumulated more total Fe and was associated with more severe symptoms than younger tissue. Media leachate Fe concentrations increased over 6 weeks and were larger at greater FeDTPA treatments. Adjustment of nutrient solution pH to 4.0, 5.25, or 6.5 did not alter media pH, nor did it prevent disorder symptoms. Application of Fe-DTPA containing nutrient solution to a soilless medium resulted in leachate Fe levels 3 times greater than for $\mathrm{FeSO}_{4}$ treatments. Chemical names used: ferric diethylenetriaminepentaacetic acid, monosodium salt (Fe-DTPA).
\end{abstract}

A specific physiological disorder affecting African and French marigolds has been reported in the floriculture industries of the United States and Canada throughout the last decade (Albano and Miller, 1993; Biernbaum et al., 1988; Carlson, 1988; Halbrooks and Albano, 1990). Symptoms of this disorder include leaf chlorosis, bronze spotting of the leaf, overall stunting, and delayed flowering (Biernbaum et al., 1988). Symptoms are observed initially on older, mature leaves, and progress to younger growth. Slight chlorotic speckling progresses to necrotic spotting (or pitting), and necrosis of leaf margins (Vetanovetz and Knauss, 1989). Early stages of the disorder may resemble spider mite damage. Affected leaf tissue has been reported to have Fe and Mn concentrations of 400-2500 ppm, which is considered excessive (Biernbaum et al., 1988). Losses in crop quality and production attributed to this disorder have been significant (Biernbaum et al., 1988). Because flowering bedding plants are valued at greater than $\$ 750$ million annually in the United States, (U.S. Dept. of Agriculture, 1993), economic losses associated with these disorders are significant.

Several trade and extension publications have identified this disorder as an Fe toxicity of some floriculture crops including New Guinea impatiens, Sultana impatiens, cutting and seed geraniums, vinca, and some species of Brassica (Vetanovetz and Kanuss, 1989). Similar disorders have been observed in cabbage and tomato transplants, and eliator begonias (Vetanovetz and Knauss, 1989). Cause of the disorder has been suggested to be low media

Received for publication 28 Apr. 1995. Accepted for publication 17 July 1995. Technical contribution no. 4146. We thank Dennis R. Decoteau, Thomas M. McInnis, Jr., and William C. Bridges, Jr., for consultation in this research, and Richard B. Brown, Eugenia R. Cocolough, and Elizabeth P. Peeler for technical assistance. This research was supported in part by The Scotts Co., The Fred C. Gloeckner Foundation, and the Clemson Univ. ornamental horticulture competitive grants program. Use of trade names does not imply endorsement of the products named nor criticism of similar ones not named. The cost of publishing this paper was defrayed in part by the payment of page charges. Under postal regulations, this paper therefore must hereby marked advertisement solely to indicate this fact.

${ }^{1}$ Graduate assistant.

${ }^{2}$ Associate professor.

${ }^{3}$ Associate professor of biology.
$\mathrm{pH}$, leading to increased availability of $\mathrm{Fe}$ and $\mathrm{Mn}$, and subsequently excess accumulation of these metals in leaves. Recommendations for control of this disorder include managing media pH (Biernbaum et al., 1988; Vetanovetz and Knauss, 1989) and water and fertilizer solution $\mathrm{pH}$ (Carlson, 1988) above critical values (6.0-6.2), thereby reducing availability of $\mathrm{Fe}$ and $\mathrm{Mn}$ in soilless media.

Disorders attributed to $\mathrm{Fe}$ toxicity include bronzing of rice, freckle leaf of sugarcane (Foy et al., 1978), grey effect in tobacco (Arnold and Binns, 1987), and various unnamed disorders in other plants. The symptomology of Fe toxicity varies with plant species and cultivar, but is generally associated with reduced plant growth and foliar expression of tissue damage. Visual symptoms of $\mathrm{Fe}$ toxicity have been reported to include necrotic pitting, spotting or speckling, and bronzing (coalesced tissue necrosis) (Albano and Halbrooks, 1991; Foy et al., 1978; Somers and Shive, 1942; Vetanovetz and Knauss, 1989; Welch and LaRue, 1990). Iron toxicity is affected by age of tissue, with the expression and susceptibility to the disorder more prevalent in older tissue of younger plants (Foy et al., 1978). The most common physiological attribute of Fe toxicity is an increase in both Fe uptake and transport to shoots and leaves (Foy et al., 1978).

Most bedding plants are grown in soilless media. Typical liquid fertilization regimes with marigolds include chelated micronutrients to maintain micronutrient availability over a wide range of rhizospheric conditions, including $\mathrm{pH}$. Iron-DTPA is one of the most commonly used Fe-chelates because DTPA has a very high affinity for $\mathrm{Fe}$ and is relatively stable in the presence of other cations (Lindsay, 1974).

Effects of continuous additions of Fe-chelates such as DTPA with fertigation applications, as would be performed in a commercial production regime using a peat-lite fertilizer, have not been studied under controlled conditions for bedding plant crops grown in soilless media. Therefore, the relationship of metal chelates, particularly Fe-DTPA, to the incidence of Fe and Mn-related toxicity disorders in marigolds needs to be established.

Despite the widespread occurrence of the disorder bronze speckle in marigolds, few data have been published in the literature 
to corroborate these reports and offer recommendations for control. The objectives of current research were 1) to induce, document, and characterize the disorder under controlled conditions; 2) to determine the relationship of the disorder to Fe-DTPA applied to a soilless medium; 3) to determine changes in $\mathrm{pH}, \mathrm{Fe}$, and $\mathrm{Mn}$ concentrations in the medium over time; 4 ) to determine the effects of nutrient solution $\mathrm{pH}$ adjustment on the occurrence of the disorder; and 5) to determine the distribution of Fe and $\mathrm{Mn}$ in symptomatic and asymptomatic leaves and between true-leaf pairs in both peat-based and hydroponic situations. This information will improve understanding of the relationship of applied metal chelates to metal uptake patterns and occurrences of similar physiological disorders in other crops grown in soilless media.

\section{Materials and Methods}

\section{Growing conditions}

Disorder induction. African 'First Lady' and 'Voyager' (Tagetes erecta L.) marigold seeds were sowed in metro-mix 360 (The Scotts Co., Marysville, Ohio) soilless medium composed of sphagnum peat moss, processed bark ash, and vermiculite in six-celled grow-packs ( $40 \mathrm{~cm}^{3} /$ cell) in a controlled environment growth chamber. A pack of six plants constituted a single replication, and six replications of each treatment and variety combination were made. Iron-DTPA treatments, $0.018 \mathrm{~mm}$ (1 ppm), $0.09 \mathrm{~mm}$ (5 ppm), $0.27 \mathrm{~mm}$ (15 ppm), or $0.36 \mathrm{~mm}(20 \mathrm{ppm})$ incorporated into a base nutrient solution were arranged in a completely randomized design within a controlled environment growth chamber programmed to deliver 10 -h photoperiods with a peak photosynthetic photon flux density of 760 $\mu \mathrm{mol} \cdot \mathrm{m}^{-2} \cdot \mathrm{s}^{-1}$, and temperatures $18-24 \mathrm{C}$ (night/day). The base nutrient solution, prepared in distilled, deionized water, was composed of the following macronutrients (in millimolar concentrations): 2.5, $\mathrm{K}_{2} \mathrm{SO}_{4} ; 2, \mathrm{MgSO}_{4} ; 0.5, \mathrm{Ca}\left(\mathrm{H}_{2} \mathrm{PO}_{4}\right)_{2} ; 2, \mathrm{CaSO}_{4} ; 7.14, \mathrm{NH}_{4} \mathrm{NO}_{3}$, and micronutrients (in micromolar concentrations): $0.046, \mathrm{H}_{3} \mathrm{BO}_{3} ; 0.76$, $\mathrm{ZnSO}_{4} ; 0.32, \mathrm{CuSO}_{4} ; 0.54, \mathrm{MoO}_{3}$; and 9.1 Mn-EDTA (manganese ethylenediaminetetraacetic acid). Plants were thinned to one plant per cell at emergence of first true-leaf pairs when treatments began. Treatment solutions $(250 \mathrm{ml})$ were applied per six-cell pack at regular intervals directly to the media (leaching fraction, 15\%-25\%), avoiding any application to foliage, throughout the experiment to maintain constant moisture. Leachate was collected on a weekly basis beginning one week after first treatment application using a modified pourthrough procedure. $12-14 \mathrm{~h}$ before leachate collection, the medium received a regular nutrient solution application. At the time of leachate collection, $250 \mathrm{ml}$ distilled, deionized water was applied per six-cell pack to the medium and leachate was collected in a clean, dry container. Leachate was stored at $4 \mathrm{C}$ and filtered prior to analysis for $\mathrm{pH}$, electrical conductivity (EC), Fe, and Mn. Plants were harvested when at least one flower was open on all plants, which was 44 days after treatments were initiated. At harvest, visual evaluations of symptom type (e.g., chlorotic speckling, necrotic speckling, or leaf curl) and severity were recorded. For tissue dry weight and elemental analysis, leaves were classified as symptomatic if any symptoms were present (regardless of severity). All remaining leaves were classified as asymptomatic.

Iron source and $\mathrm{pH}$. This study was designed to test the hypothesis that adjusting nutrient solution $\mathrm{pH}$ is an effective means of avoiding the disorder associated with high levels of $\mathrm{Fe}$ in affected tissue of marigold. 'First Lady' marigold germination, environmental conditions, and base nutrient solution formulation were as described in the disorder induction experiment, except that treatments were initiated when true leaf-pair 3 was emerging. The experiment was a completely randomized design with 6 treatments consisting of combinations of nutrient solution $\mathrm{pH}$ (4.0, 5.25, or 6.5 , adjusted with $\mathrm{HCl}$ or $\mathrm{NaOH})$ and $\mathrm{Fe}$ source $\left[\mathrm{FeSO}_{4}\right.$ or Fe-DTPA, at $\left.0.018 \mathrm{~mm}(1 \mathrm{ppm} \mathrm{Fe})\right]$. Plants were harvested 36 days after the emergence of first true-leaf pairs when at least one flower was open on each plant.

Leaf metal-media. 'First Lady' marigold germination, environmental conditions, and base nutrient formulation were as described in disorder induction. The major differences in this experiment were that 1) plants were grown in $330 \mathrm{~cm}^{3}$ containers, and 2) tissue harvesting occurred by true-leaf pair, numbering from the stem base upwards. The experiment was a completely randomized design with three Fe-DTPA treatments $[0,0.018 \mathrm{~mm}$ (1 ppm), and $0.18 \mathrm{~mm}(10 \mathrm{ppm})]$, and six replications per treatment. Plants were irrigated with quarter-strength nutrient solution prior to the initiation of treatments at the emergence of the first true-leaves. Treatment solutions were adjusted to $\mathrm{pH} 5.8$ with $\mathrm{NaOH}$ or $\mathrm{HCl}$, and applied directly to the media at intervals appropriate to maintain adequate moisture at the rate of $150 \mathrm{ml}$ per container. At harvest, 28 days after initiating treatments, visual evaluations of symptom type (e.g., chlorotic speckling, necrotic speckling, or leaf curl) and severity were recorded for each trueleaf pair. True-leaf pairs of common stem origin in each treatment were combined to form single pooled samples. Plant height was determined by measuring length of primary shoot from cotyledon node to shoot apex.

Leaf metal-hydroponics. This experiment was conducted simultaneously with leaf metal-media in the same growth chamber with the following modifications: 1) plants were grown hydroponically in the same nutrient solutions used in the media experiment, and 2) aerated treatment solutions were changed every 3 days.

\section{Mineral determination}

Leaf tissue was washed in $0.2 \mathrm{~N} \mathrm{HCl}$ and double rinsed with distilled, deionized water, and dried in a forced-air oven at $75 \mathrm{C}$ for $24 \mathrm{~h}$. Leaf dry weight was recorded and the tissue was milled or ground to pass through a 20-mesh screen. One g of leaf tissue was dry ashed at 500C for $5 \mathrm{~h}$ and prepared for elemental analysis with a modified digestion procedure (Allen et al., 1986) (Perkin-Elmer, 1982). Modifications included 1) $15.8 \mathrm{~N} \mathrm{HNO}_{3}$ was added to wet the ash residue after cooling, 2) wet ash residue was placed on a hot plate at $\approx 80 \mathrm{C}$ until dry, 3) ash was rewetted with $8 \mathrm{ml}$ of $6 \mathrm{~N} \mathrm{HCl}$ and scraped with a plastic spatula, 4) ash solution was quantitatively transferred to a $100 \mathrm{ml}$ volumetric flask and brought to volume with distilled, deionized water, and 5) solution was filtered through filter paper (no. 41; Whatman Paper, Maidstone, Kent., U.K.). Tissue extracts and leachates were analyzed by atomic absorption spectrophotometry for $\mathrm{Fe}$ and $\mathrm{Mn}$.

Statistics. Data from the disorder induction and Fe source and $\mathrm{pH}$ experiments were analyzed to determine the main effect of variety and Fe treatments, and to determine the presence of interaction between these factors by using an ANOVA. Calculations were performed with the general linear model (GLM) procedure of SAS (SAS Inst., Cary, N.C.). Where a significant F test was observed, means were separated and planned comparisons were made using pairwise $t$ tests.

\section{Results}

\section{Disorder induction}

Disorder development and characteristics. The earliest visual symptoms of the bronze speckle disorder were patches of interveinal chlorosis (Fig. 1A) that became more speckled and then developed 
into, or were associated with, necrotic speckles on leaflets towards the distal end of the leaf blade (Fig. 1B). The necrotic speckles were bronze and occasionally shiny, becoming brown with time. Bronze speckles were concentrated initially on the leaflet margin progressing toward the central vein. Concurrently, the leaflet(s) curled downward (Fig. 1C). As symptoms became more severe, more necrotic speckles formed, downward curling of leaflets became more exaggerated, and a larger portion of the leaf was affected (Fig. 1D). In the most severe cases, necrotic speckles coalesced so that entire leaves became necrotic.

Within 3 days of the first application of $0.36 \mathrm{mmFe}$-DTPA, both cultivars exhibited necrotic speckling on cotyledons. Within 7 days, necrotic speckling appeared on first true-leaf pairs of both cultivars treated with $0.27 \mathrm{~mm}$ Fe-DTPA. Symptoms predominately affected the older leaves of 'First Lady', with fewer symptoms on younger leaves; whereas in 'Voyager', symptoms occurred more frequently in younger than in older leaves.

Leaf dry weight. There were no differences in total leaf dry weight between treatments or cultivars (Table 1); averaging 0.48 g/plant. 'First Lady' and 'Voyager' had little or no symptomatic
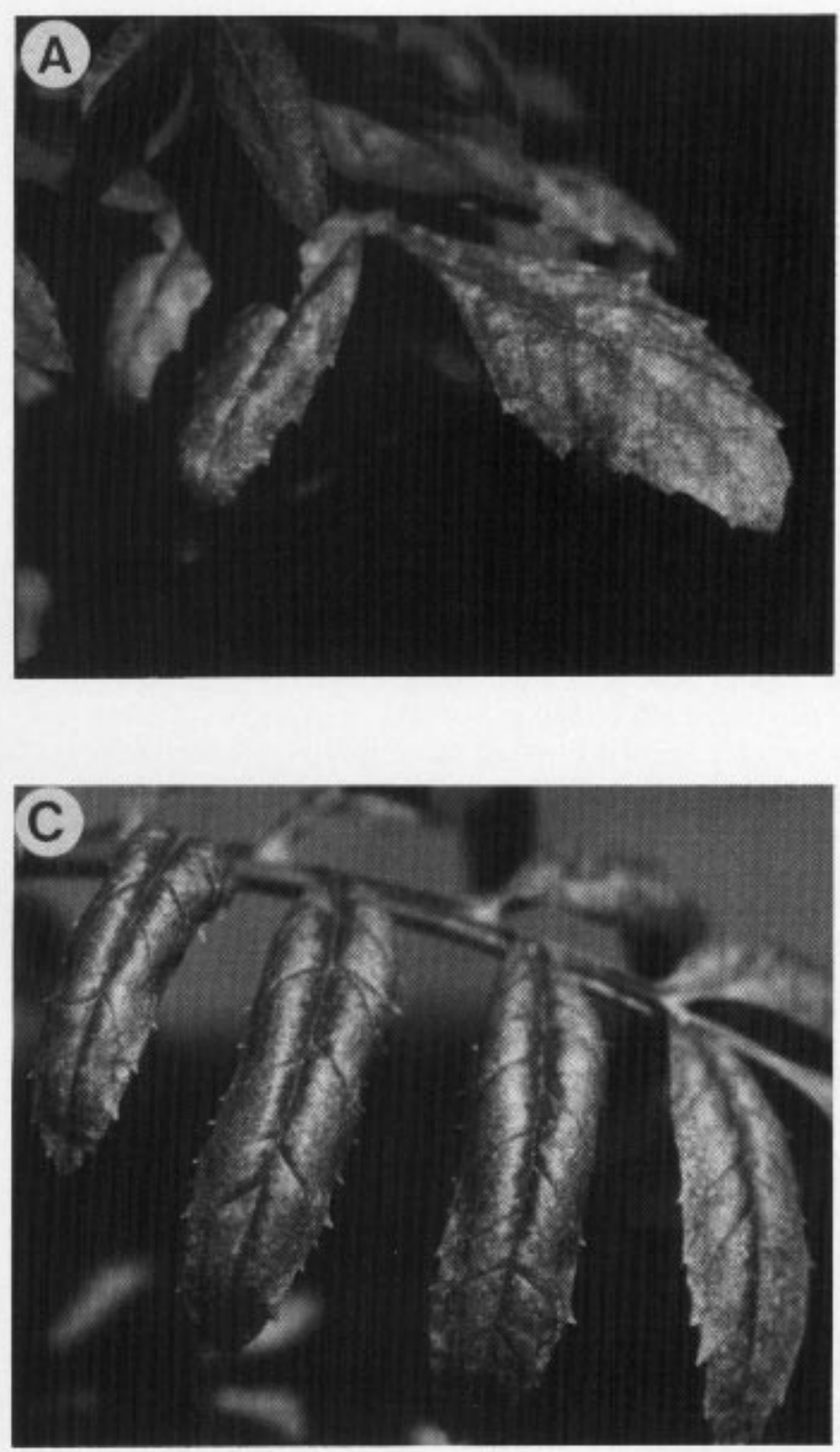

tissue at 0.018 and $0.09 \mathrm{~mm}$ Fe-DTPA; averaging $<0.2 \mathrm{~g} / \mathrm{plant}$ (Table 1). Symptomatic dry weight significantly increased between 0.09 and $0.36 \mathrm{~mm}$ Fe-DTPA for 'Voyager' (Table 1). Both 'First Lady' and 'Voyager' treated with 0.27 and $0.36 \mathrm{~mm} \mathrm{Fe}$ DTPA had significantly higher symptomatic than asymptomatic leaf tissue (Table 1).

Leachate $\mathrm{pH}$ and $\mathrm{Fe}$ concentrations. Leachate $\mathrm{pH}$ decreased over the course of the experiment but was similar for all treatments and both cultivars; averaging 5.9 at week 1 and 4.4 at week 6 (Table 2). Conversely, leachate Fe concentration was highly dependent on the concentration of Fe-DTPA applied (Table 2). Within the first week, leachate Fe concentrations began increasing rapidly, and by week 6 , leachate Fe levels were much higher than actual treatment Fe-DTPA concentrations, on average, double the concentration applied (Table 2).

Leaf Fe and Mn concentrations. For both cultivars, there was a linear increase in Fe concentration in asymptomatic tissue as $\mathrm{Fe}$ DTPA treatment increased. As a mean of all treatments, 'First Lady' had a significantly greater Fe concentration in asymptomatic tissue than 'Voyager' at 755 and $636 \mu \mathrm{g} \cdot \mathrm{g}^{-1}$, respectively (Table 1).
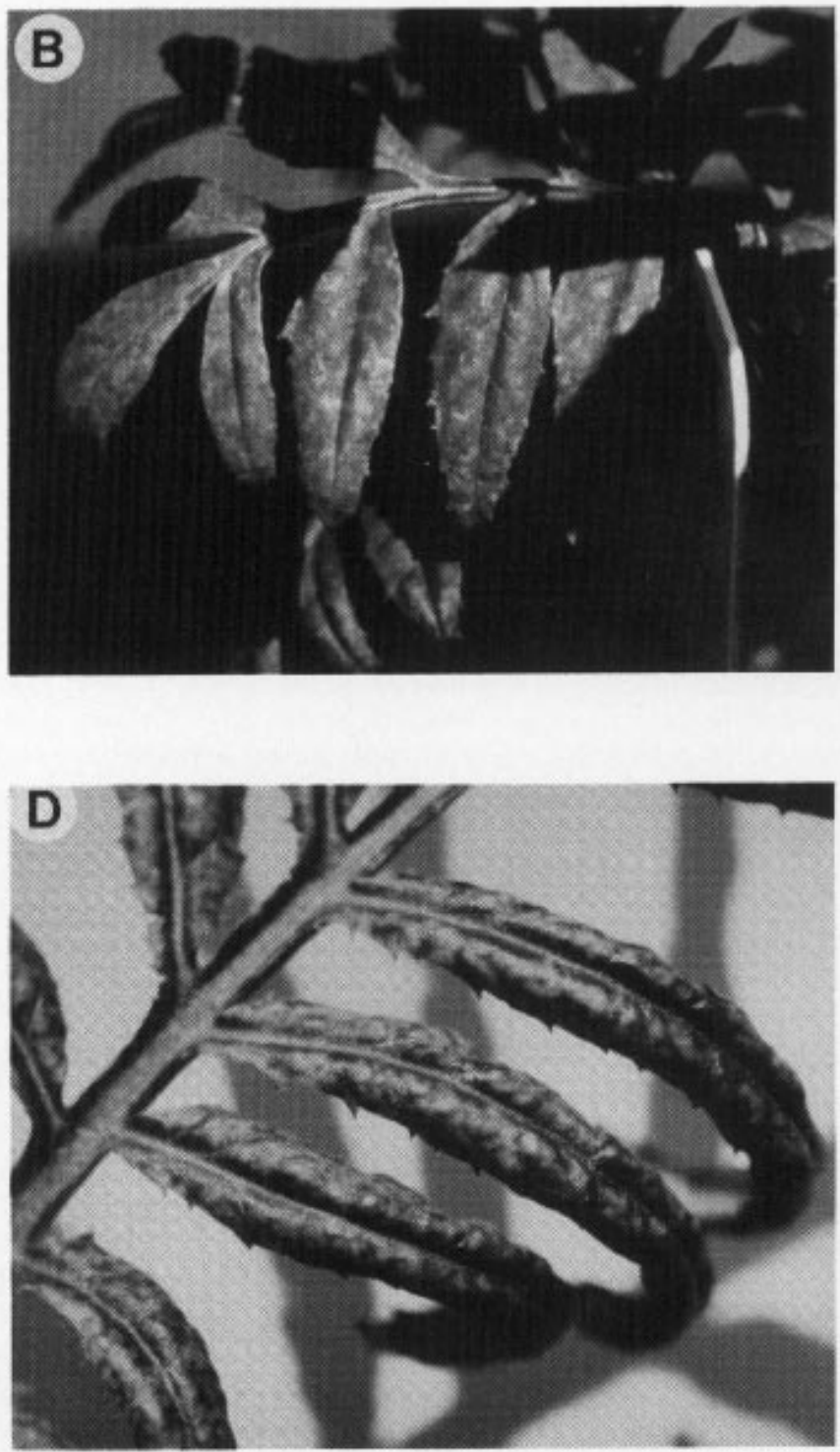

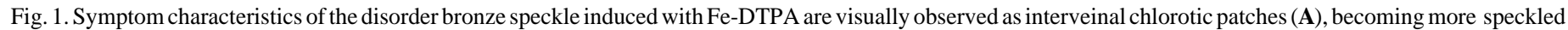
as symptoms progress (B). Severe symptom characteristics of the disorder induced with Fe-DTPA include necrotic speckling (C) and leaflet curl (D). 
Table 1. Leaf dry weight and Fe concentration for asymptomatic and symptomatic marigold tissues at harvest at first open flower, 44 days after treatments began for the disorder induction experiment.

\begin{tabular}{|c|c|c|c|c|c|}
\hline \multirow[b]{3}{*}{ Cultivar } & \multirow[b]{3}{*}{ Fe-DTPA (mM) } & \multicolumn{4}{|c|}{ Leaf tissue } \\
\hline & & \multicolumn{2}{|c|}{ Dry wt $(\mathrm{g})$} & \multicolumn{2}{|c|}{ Fe concn $\left(\mu g \cdot g^{-1}\right)$} \\
\hline & & Asymptomatic & Symptomatic & Asymptomatic & Symptomatic \\
\hline \multirow{4}{*}{ 'First Lady' } & 0.018 & $0.46 \mathrm{a}^{\mathrm{z}}$ & --- & $561 \mathrm{a}$ & --- \\
\hline & 0.09 & $0.50 \mathrm{a}$ & --- & $640 \mathrm{ab}$ & --- \\
\hline & 0.27 & $0.14 \mathrm{~b}$ & $0.30 \mathrm{a}^{* *}$ & $754 \mathrm{~b}$ & $1030 \mathrm{a}^{* *}$ \\
\hline & 0.36 & $0.08 \mathrm{~b}$ & $0.37 \mathrm{a}^{* * * *}$ & $1144 \mathrm{c}$ & $1647 \mathrm{~b}^{* * * *}$ \\
\hline \multirow[t]{4}{*}{ 'Voyager' } & 0.018 & $0.52 \mathrm{a}$ & --- & $483 \mathrm{a}$ & --- \\
\hline & 0.09 & $0.39 \mathrm{~b}$ & $0.18 \mathrm{a}^{* * * *}$ & $573 \mathrm{ab}$ & $1022 a^{*}$ \\
\hline & 0.27 & $0.13 \mathrm{c}$ & $0.30 \mathrm{~b}^{* * * *}$ & $679 \mathrm{bc}$ & $1195 \mathrm{a}^{* *}$ \\
\hline & 0.36 & $0.06 \mathrm{c}$ & $0.42 \mathrm{c}^{* * * *}$ & $808 \mathrm{c}$ & $1171 \mathrm{a}^{*}$ \\
\hline
\end{tabular}

${ }^{\mathrm{z}}$ Means within a column of a cultivar followed by different letters indicate significant differences between treatments at $P=0.05$, pairwise $t$ test.

${ }^{*},{ }^{* *},{ }^{* * *}$ Significant differences between asymptomatic and symptomatic leaf tissue within a treatment at $P=0.05,0.01$, and 0.001 , respectively, pairwise $t$ test.

Table 2. Leachate $\mathrm{pH}$ and Fe concentration $\left(\mathrm{mg} \cdot \operatorname{liter}^{-1}\right)$ for the disorder induction experiment.

\begin{tabular}{|c|c|c|}
\hline \multirow[b]{2}{*}{ Fe-DTPA (mM) } & \multicolumn{2}{|c|}{ Week } \\
\hline & 1 & 6 \\
\hline \multicolumn{3}{|c|}{$p H$} \\
\hline 0.018 & 5.88 & $4.27^{\text {**** }}$ \\
\hline 0.09 & 5.87 & $4.32^{* * * *}$ \\
\hline 0.27 & 5.91 & $4.42^{* * * *}$ \\
\hline 0.36 & 6.06 & $4.47^{* * * *}$ \\
\hline \multicolumn{3}{|c|}{$\mathrm{Fe}$} \\
\hline 0.018 & 0.91 & $2.22^{\mathrm{NS}}$ \\
\hline 0.09 & 4.31 & $10.53^{* * * *}$ \\
\hline 0.27 & 14.54 & $23.52^{* * * *}$ \\
\hline 0.36 & 19.68 & $31.52^{* * * *}$ \\
\hline
\end{tabular}

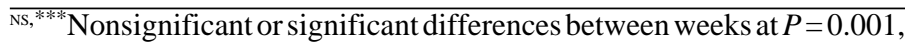
pairwise $t$ test.

Iron concentration in symptomatic tissue was always significantly higher than asymptomatic tissue for both cultivars (Table 1), and Fe concentration in symptomatic tissue, as a mean of all treatments, was again a little higher in 'First Lady' than 'Voyager' at 1339 and $1151 \mu \mathrm{g} \cdot \mathrm{g}^{-1} \mathrm{Fe}$, respectively. For both cultivars and for all treatments, the highest Fe concentration in asymptomatic leaf tissue was in 'First Lady' $0.036 \mathrm{~mm}$ Fe-DTPA treatment at 1144 $\mu \mathrm{g} \cdot \mathrm{g}^{-1}$, and the lowest Fe concentration in symptomatic leaf tissue was in 'Voyager' $0.09 \mathrm{~mm}$ Fe-DTPA treatment at $1022 \mu \mathrm{g} \cdot \mathrm{g}^{-1}$. This suggest a critical toxic Fe concentration in leaf tissue for these cultivars between 1000 and $1200 \mu \mathrm{g} \cdot \mathrm{g}^{-1}$.

Leaf Mn was similar for both cultivars at all treatment levels averaging $301 \mu \mathrm{g} \cdot \mathrm{g}^{-1} \mathrm{Mn}$ (data not shown). Within an Fe-DTPA level, Fe in symptomatic tissue was 2.5, 3.5, and 3.1 times greater than $\mathrm{Mn}$ in 'Voyager' treatments delivering $0.09,0.27$, and 0.36 mM Fe-DTPA, respectively; and 3 and 5 times greater for 'First Lady' treatments delivering 0.27 and $0.36 \mathrm{~mm}$ Fe-DTPA, respectively (data not shown).

\section{Iron source and $\mathbf{p H}$}

Disorder development and characteristics. Generally, symptoms for 'First Lady' were consistent with those expressed on plants in the disorder induction experiment. Interveinal chlorosis was the most prevalent symptom along with a small amount of necrotic speckling and some downward curling of leaves. Symp- toms first appeared on third and fourth true-leaf pairs and on axial leaves, which had not been noted in earlier experiments but can probably be explained by the initiation of treatments with development of true-leaf pair 3. Symptoms were similar between all treatments.

Leafdry weight. Total leaf dry weight did not differ between Fe source or $\mathrm{pH}$ treatment, and averaged $0.62 \mathrm{~g} / \mathrm{plant}$ (data not shown). Across all $\mathrm{pH}$ and Fe source treatments, leaf dry weight was much greater in asymptomatic than symptomatic tissue, averaging $0.49 \mathrm{~g}$ and $0.13 \mathrm{~g} /$ plant, respectively.

Leachate $\mathrm{pH}$ and $\mathrm{Fe}$ concentrations. Iron source affected leachate $\mathrm{pH}$. Nutrient solution $\mathrm{pH}$ had no effect. Generally, medium leachate $\mathrm{pH}$ decreased with both $\mathrm{Fe}$ sources, however, after week 2, pH was lower with Fe-DTPA than $\mathrm{FeSO}_{4}$ (Table 3). Leachate $\mathrm{Fe}$ concentrations increased rapidly during the first 4 weeks with Fe-DTPA then decreased; while $\mathrm{FeSO}_{4}$ showed no significant change (data not shown). The final leachate Fe concentration for Fe-DTPA was 3-fold greater than for $\mathrm{FeSO}_{4}(2.3 \mathrm{ppm}$ vs $0.73 \mathrm{ppm} \mathrm{Fe}$ ), and 2.3-fold greater than the concentration of FeDTPA being applied (Table 3), consistent with leachate data from disorder induction experiment.

Leaf Fe and Mn concentrations. Leaf Fe and Mn concentrations did not differ between Fe source and solution $\mathrm{pH}$ treatments (data not shown). Iron and $\mathrm{Mn}$ concentrations (as a mean of all $\mathrm{pH}$ and Fe treatments) in symptomatic and asymptomatic leaf tissue aver-

Table 3. Leachate $\mathrm{pH}$ and $\mathrm{Fe}$ concentration $\left(\mathrm{mg} \cdot \mathrm{liter}^{-1}\right)$ as a mean of $\mathrm{pH}$ treatments $4.0,5.25$, and 6.5 for the Fe source and $\mathrm{pH}$ experiment.

\begin{tabular}{lcc}
\hline \hline & \multicolumn{2}{c}{ Week } \\
\cline { 2 - 3 } Iron source $^{z}$ & $p H$ & 5 \\
\hline & 1 & $4.44 \mathrm{a}^{* * * *}$ \\
$\mathrm{FeSO}_{4}$ & $5.40 \pm 0.06 \mathrm{a}^{\mathrm{y}}$ & $4.64 \mathrm{~b}^{* * *}$ \\
$\mathrm{Fe}^{\text {DTPA }}$ & $5.45 \pm 0.03 \mathrm{a}$ & \\
$\mathrm{FeSO}_{4}$ & $\mathrm{Fe}$ & $0.75 \mathrm{a}^{\mathrm{Ns}}$ \\
Fe-DTPA & $0.90 \pm 0.02 \mathrm{a}$ & $2.30 \mathrm{~b}^{* * *}$ \\
\hline
\end{tabular}

${ }^{\mathrm{z}}$ Fe supplied at $0.018 \mathrm{~mm}$.

${ }^{\mathrm{y}}$ Means followed by different letters indicates significant differences between Fe source at $P=0.01$, pairwise t test.

Ns,**,**** Nonsignificant or significant differences between weeks at $P=$ 0.01 and 0.001 , respectively, pairwise $t$ test. 

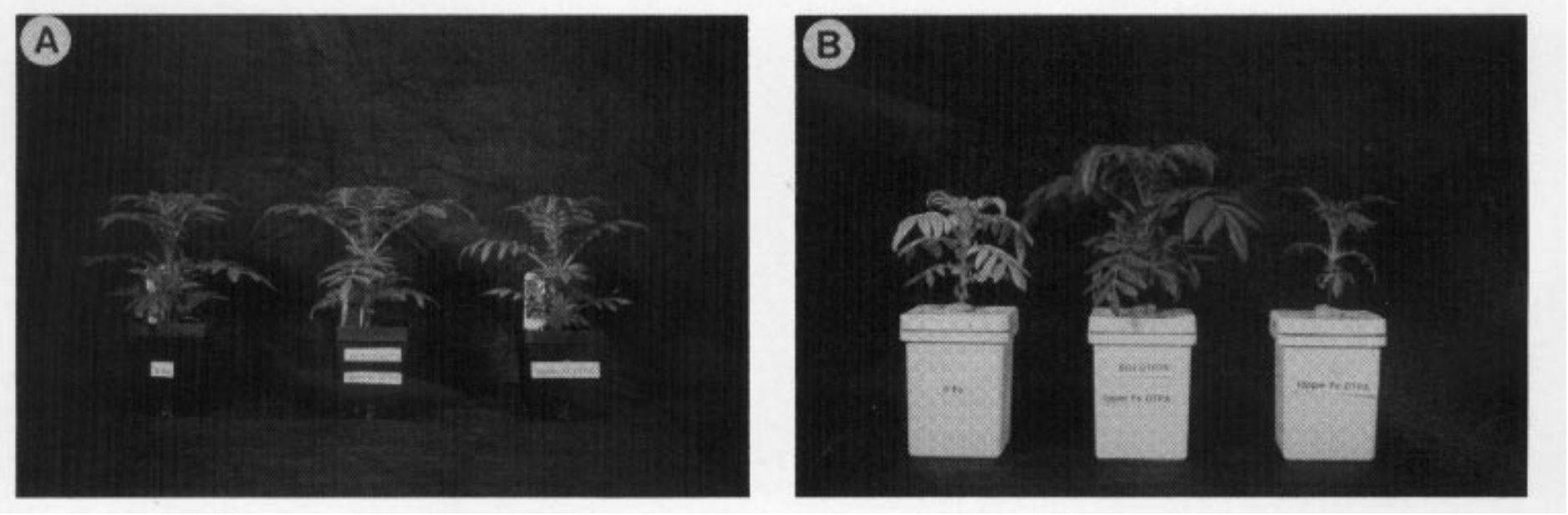

Fig. 2. Representative plants of $0,0.018 \mathrm{~mm}(1 \mathrm{ppm})$, and $0.18 \mathrm{~mm}(10 \mathrm{ppm})$ Fe-DTPA treatments (left to right) after 30 days of growth in soilless media (A) and hydroponics (B).

aged $1586 \mu \mathrm{g} \cdot \mathrm{g}^{-1} \mathrm{Fe}$ and $1355 \mu \mathrm{g} \cdot \mathrm{g}^{-1} \mathrm{Mn}$, and $731 \mu \mathrm{g} \cdot \mathrm{g}^{-1} \mathrm{Fe}$ and 942 $\mu \mathrm{g} \cdot \mathrm{g}^{-1} \mathrm{Mn}$, respectively.

\section{Leaf metal-media and leaf metal-hydroponics}

Disorder development and characteristics. Plants grown in soilless media were less affected by Fe deficient ( 0 Fe-DTPA) and excess $(0.18$ mм Fe-DTPA) treatments than plants grown in hydroponics (Fig. 2). When grown in soilless media, plant height was similar between treatments, averaging $14 \mathrm{~cm}$, whereas in solution culture grown plants, the 0 Fe-DTPA and $0.18 \mathrm{~mm} \mathrm{Fe}$ DTPA treatments were half as tall as plants in the $0.018 \mathrm{~mm} \mathrm{Fe}$ DTPA treatment which averaged $12 \mathrm{~cm}$. In both the leaf metalmedia and leaf metal-hydroponics experiments, plants in the $0.18 \mathrm{~mm}$ Fe-DTPA treatment developed characteristic symptomology of the disorder, and symptoms developed 4 and 7 days after initiating treatment, respectively. In hydroponics, plants of the 0 Fe-DTPA treatment showed visual symptoms of $\mathrm{Fe}$ deficiency, mild interveinal chlorosis, on newly forming leaves 7 days after initiating treatment. Leaves forming subsequent to day 7 were progressively more Fe-deficient with the most severe leaves entirely chlorotic (yellow to pale yellow-white) with marginal and spotty interveinal necrosis. Plants in the media $0 \mathrm{Fe}-$ DTPA treatment did not develop symptoms of Fe deficiency.

Leaf $\mathrm{Fe}$ and $\mathrm{Mn}$ concentrations. In both soilless media and hydroponic systems, a correlation between leaf Fe accumulation and the occurrence of the disorder bronze speckle was documented with symptom severity and frequency increasing with leaf $\mathrm{Fe}$ and leaf age. The disorder developed only in true-leaf pairs $1-5$ in the $0.18 \mathrm{~mm} \mathrm{Fe}-$ DTPA treatment in leaf metal-media, and true-leaf pairs 1-3 in the $0.18 \mathrm{~mm}$ Fe-DTPA treatment in leaf metal-hydroponics (Table 4). In both soilless media or hydroponics, symptomatic leaf pairs had at least 4-fold higher $\mathrm{Fe}$ concentrations than the corresponding asymptomatic leaf pairs in the 0 Fe-DTPA and $0.018 \mathrm{~mm}$ Fe-DTPA treatments (Table 4). Elimination of Fe in hydroponics resulted in high uptake of Mn into leaves, averaging $1172 \mu \mathrm{g} \cdot \mathrm{g}^{-1}, 3.7$-times and 1.9-times greater than in leaves of the 0.018 and $0.18 \mathrm{~mm}$ treatments averaging $314 \mu \mathrm{g} \cdot \mathrm{g}^{-1}$ and $629 \mu \mathrm{g} \cdot \mathrm{g}^{-1}$, respectively (Table 4).

In the leaf metal-media experiment, the Mn concentration in leaf tissue was highest in true-leaf pair 1 , decreasing with subsequent leaf pairs and remaining nearly constant for leaf pairs 4-7 (Table 4).

\section{Discussion}

Disorder induction and Fe source and $\mathrm{pH}$. Symptoms of the disorder induced in marigolds with Fe-DTPA were consistent with those described as an Fe toxicity disorder (Biernbaum et al., 1988; Carlson, 1988). The unique pattern of symptom development that characterizes the disorder begins with patches of interveinal chlorosis of mature leaves, progressing to distinct chlorotic and bronze speckling, and pitting. Increased severity of symptoms with increasing Fe-DTPA concentrations as observed visually was confirmed by leaf dry weight distribution.

At lower Fe-DTPA concentrations [e.g., $0.018 \mathrm{~mm}(1 \mathrm{ppm} \mathrm{Fe})$ Fe-DTPA], symptoms appeared only on younger leaves and always included chlorotic speckling. Symptom progression to more advanced speckling or necrotic pitting did not always occur. At higher Fe-DTPA concentrations, symptoms appeared earlier, progressed more rapidly, and were more severe at harvest.

In the Iron source and $\mathrm{pH}$ experiment, development of symptoms in plants supplied with $0.018 \mathrm{~mm}$ Fe-DTPA was not consistent among plants of any Fe source or $\mathrm{pH}$ treatment as some plants developed no symptoms at all. Symptoms of the disorder, however, occurred at $\mathrm{Fe}$ concentrations similar to those applied in typical production regimes (1 ppm $\mathrm{Fe})$ and in the presence or absence of chelated Fe. However, Mn was supplied as Mn-EDTA, 
Table 4. Iron and Mn concentration $\left(\mu \mathrm{g} \cdot \mathrm{g}^{-1}\right)$ in true-leaf pairs 1-7 (numbering from stem base upwards) for the Leaf metal - media and Leaf metal-hydroponics experiments, treatments $0,0.018 \mathrm{mM}$, and $0.18 \mathrm{mM}$ Fe-DTPA. Plants were harvested 28 days after treatments began.

\begin{tabular}{|c|c|c|c|c|c|c|c|c|}
\hline \multirow[b]{2}{*}{ Experiment } & \multirow{2}{*}{$\begin{array}{c}\text { Treatment } \\
\text { Fe-DTPA }(\mathrm{mM})\end{array}$} & \multicolumn{7}{|c|}{ True-leaf pair and metal content $\left(\mu \mathrm{g} \cdot \mathrm{g}^{-1}\right)$} \\
\hline & & 1 & 2 & 3 & 4 & 5 & 6 & 7 \\
\hline \multicolumn{9}{|c|}{$\mathrm{Fe}$} \\
\hline Leaf Metal & 0 & 231 & 154 & 115 & 124 & 133 & 136 & 131 \\
\hline Media & 0.018 & 613 & 359 & 140 & 135 & 140 & 144 & 129 \\
\hline \multicolumn{9}{|c|}{$\begin{array}{r}1640^{z} \\
M n\end{array}$} \\
\hline & 0 & 465 & 417 & 393 & 313 & 279 & 280 & 286 \\
\hline & 0.018 & 727 & 523 & 305 & 279 & 255 & 237 & 229 \\
\hline \multicolumn{9}{|c|}{$\mathrm{Fe}$} \\
\hline Leaf Metal & 0 & 89 & 66 & 50 & 60 & 46 & 92 & 64 \\
\hline Hydroponics & 0.018 & 910 & 515 & 340 & 232 & 224 & 421 & 247 \\
\hline & 0.18 & $13164^{z}$ & $3074^{z}$ & $906^{\mathrm{z}}$ & 334 & 289 & 245 & 230 \\
\hline \multicolumn{9}{|c|}{$M n$} \\
\hline & 0 & 1519 & 1574 & 1439 & 1200 & 967 & 778 & 729 \\
\hline & 0.018 & 683 & 332 & 252 & 190 & 175 & 371 & 195 \\
\hline & 0.18 & 2499 & 975 & 380 & 145 & 113 & 134 & 158 \\
\hline
\end{tabular}

${ }^{\mathrm{Z}}$ Indicates that at least one true-leaf pair had the disorder bronze speckle at harvest.

which is a relatively unstable chelate complex. Therefore, Fe could have replaced $\mathrm{Mn}$ as the ligand-held ion, thereby increasing available Fe levels relative to that which might be available if free Fe was applied in the absence of a chelate (Norvell and Lindsay, 1969). Symptoms were similar among plants treated with $\mathrm{pH}-$ adjusted nutrient solution of $4.0,5.25$, or 6.5 , indicating that $\mathrm{pH}$ adjustment of irrigation water is not a reliable method of preventing this disorder in marigolds.

In the disorder induction experiment, Fe concentrations in symptomatic and asymptomatic leaves increased with increasing Fe-DTPA concentrations. Iron concentrations in symptomatic leaves were consistently higher than in asymptomatic leaves. In contrast, Mn concentrations were similar in symptomatic and asymptomatic tissue in plants grown over a range of Fe-DTPA concentrations. Mn toxicity has been reported for several crops and is typically associated with leaf crinkling, cupping, or curling, interveinal tissue puckering (raised areas of tissue between major veins), interveinal chlorosis, and bronze necrotic spotting and pitting (Hannam and Ohki, 1988). Mn toxicity induced in 'First Lady' in hydroponics with $0.36 \mathrm{~mm} \mathrm{MnCl}_{2}$ (20 ppm Mn) was characterized by leaf puckering and crinkling, with shiny bronze or copper necrotic pits of irregular size, shape, and distribution (Fig. 3). Symptoms associated with Mn toxicity were distinguishable from those associated with the disorder bronze speckle induced with Fe-DTPA. These observations and the lack of a consistent accumulation pattern of Mn associated with symptomatic tissue indicates that Mn toxicity is not the direct cause of bronze speckle.

In addition to asymptomatic leaf dry weights decreasing with increasing Fe treatment in experiment disorder induction, the concentration of leaf Fe in asymptomatic leaf tissue increased in both cultivars as well. For 'First Lady', Fe concentration in asymptomatic leaf tissue in the $0.36 \mathrm{~mm}$ Fe-DTPA treatment was 1.1 -fold greater than in symptomatic leaf tissue in the $0.27 \mathrm{~mm} \cdot \mathrm{g}^{-1} \mathrm{Fe}$-DTPA treatment. The apparent acquired tolerance to excessive Fe may be due to the induction and production of the Fe storage protein, phytoferritin. Ferritin is an Fe induced protein that can function as a cellular Fe buffer (Bienfait and van der Mark, 1983; Thiel, 1987; van der Mark et al., 1981). It has been proposed that tolerance to Fe toxicity in plants may involve the ferritin system (Verkleji and Schat, 1990). Therefore, future studies should test this hypothesis by quantifying ferritin in symptomatic and asymptomatic leaf tissue at increasing Fe-DTPA treatment levels for 'First Lady'.

The role of the chelating agent, in this case DTPA, to the disorder and increased levels of Fe in affected tissue of marigold is likely as a supplier of $\mathrm{Fe}$ to roots rather than as a toxic agent itself. It is accepted that chelates act by keeping the metal available in the soil solution, and therefore enhance Fe absorption and increase $\mathrm{Fe}$ concentrations in root and shoot tissues. It is now considered likely that the chelate itself is only absorbed in very small quantities relative to Fe uptake in plant tissue (Chaney, 1988; Romheld and Marschner, 1983). In zinnia (Zinnia elegans Jacq.), sunflower (Helianthus annuus L.) and soybean (Glycine max L.) plants supplied with Fe-EDDHA in nutrient solution, Fe concentrations of exudate from decapitated plants was 8-times higher than the nutrient solution $\mathrm{Fe}$ concentration. The average ratio of chelated $\mathrm{Fe}$ (Fe-EDDHA) to total Fe in the exudate was 1:12 (Tiffin et al., 1960). Peanut plants (Arachis hypogaea L.) subjected to Fe deficiency increased their capacity to take up Fe from a Fe-EDDHA solution with no corresponding increase in the uptake of the chelating agent, EDDHA (Romheld and Marschner, 1983). Thus, it is likely that DTPA itself is not the phytotoxic agent of this disorder in marigold.

Changes in leachate $\mathrm{pH}$ and Fe concentrations over time were similar in the disorder induction and Fe source and $\mathrm{pH}$ experiments. Generally, pH decreased with time due to solubility and leaching of pre-incorporated $\mathrm{CaCO}_{3}$ (lime) from the media. A similar pattern of $\mathrm{pH}$ in media is expected in commercial regimes using water low in bicarbonates and fertilizer high in $\mathrm{NH}_{4}-\mathrm{N}$. Changing media $\mathrm{pH}$ from 4 to 7 by liming is not likely to greatly affect availability of Fe complexed with DTPA because Fe-DTPA is fairly stable within this range (Lindsay, 1979). Boxma (1981) reported that over $95 \%$ and $50 \%$ of Fe-DTPA applied to a peatbased media at $\mathrm{pH} 5.65$ and 7.25 ( $\mathrm{pH}$ adjusted with $\mathrm{CaCO}_{3}$ ), respectively, remained water-soluble after 3 days incubation. Leachate $\mathrm{pH}$ changes in the $\mathrm{Fe}$ source and $\mathrm{pH}$ experiment indicate that adjustment of irrigation water or fertilizer solution $\mathrm{pH}$ has no 


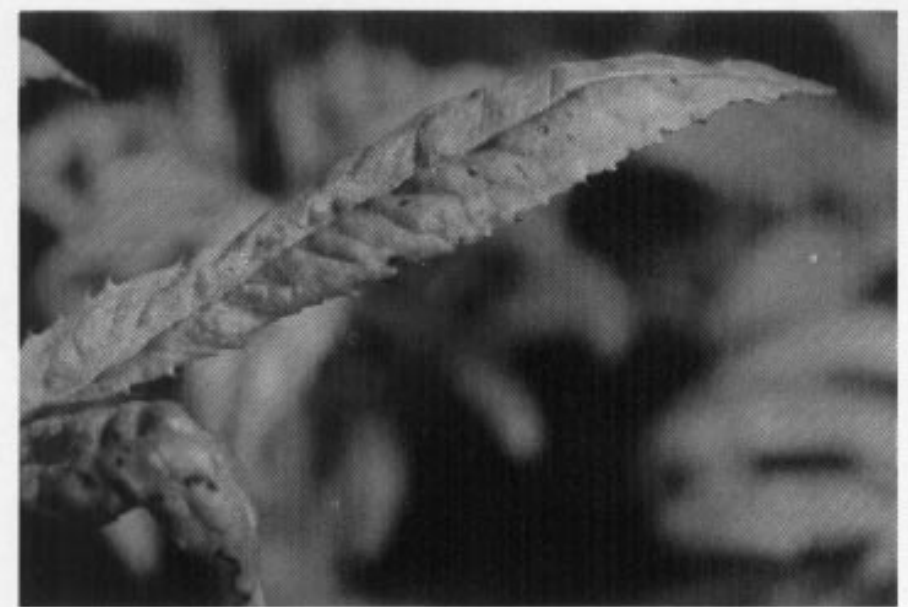

Fig. 3. Manganese toxicity induced in 'First Lady' marigold with $0.36 \mathrm{~mm}(20 \mathrm{ppm}) \mathrm{MnCl}_{2}$.

affect on media $\mathrm{pH}$ (likely due to buffering capacity of peat, residual $\mathrm{CaCO}_{3}$, and high $\mathrm{NH}_{4}-\mathrm{N}$ ) or the occurrence of symptoms.

Leachate Fe concentrations increased over time in the disorder induction and $\mathrm{Fe}$ source and $\mathrm{pH}$ experiments, and were higher with correspondingly higher Fe-DTPA treatments and the use of chelated vs. unchelated Fe sources. Availability of metals for plant uptake from solid phase sources of peats has been estimated by extraction methods adapted from those used in mineral soils (Markus et al., 1981) and peats vary widely in metal content, particularly Fe (Handreck, 1989; Mitchell, 1954; Walsh and Barry, 1958). Chelates extract Fe from peat and extractable Fe concentration varies widely with peat source (Broschat and Donselman, 1985; Handreck, 1989). DTPA is a more reliable indicator of medium micronutrient status than EDTA (Berghage et al., 1987). Our data indicate that frequent additions of Fe-chelates, as would be performed in a commercial production regime using a peat-lite fertilizer, will increase the level of leachable Fe from a peat-based medium to a concentration greater than that being applied due to the extraction properties of the chelate.

Leafmetal—media and leafmetal-hydroponics. In leaf metalhydroponics, Mn uptake into leaves of the $0 \mathrm{Fe}$ treatment was greater than for any other treatment of leaf metal-hydroponics or leaf metal-media. This is an example of the competitively antagonistic relationship of $\mathrm{Fe}$ and $\mathrm{Mn}$ in solution culture where low levels of Fe solution results in high uptake of Mn (Warden and Reisenauer, 1991). The cause of increased Mn uptake when Fe is low may be due to an enhanced rhizodermal reductase activity expressed by Fe-efficient, strategy I plants (dicots and nongraminaceous monocots) (Bienfait, 1988). Marschner et al. (1982) demonstrated that $\mathrm{Fe}$-deficient sunflower plants had a greater ability to reduce $\mathrm{MnO}_{2}$ to $\mathrm{Mn}$ (II) as well as $\mathrm{Fe}$ (III) to $\mathrm{Fe}$ (II) than $\mathrm{Fe}$ sufficient sunflower plants.

Visual symptoms of Fe deficiency were not evident in the media 0 Fe treatment over the 28 day course of the experiment. These plants apparently were able to acquire Fe from the soilless medium itself, possibly from the incorporated nutrient starter charge or via Fe-efficiency reactions.

In conclusion, several factors that may influence Fe availability (iron source and $\mathrm{pH}$ experiment), uptake, and occurrence of an Fe toxicity physiological disorder in African marigolds (disorder induction, leaf metal-media, and leaf metal-hydroponics ) have been identified in this study. The widespread use of metal chelates in the production of floriculture crops raises the possibility that chelates may be a common factor in the disorder. There does not appear to be a critical concentration of Fe associated with symptom occurrence, suggesting that tolerance to Fe concentrations in tissue varies depending on available Fe levels. Concentrations of FeDTPA [e.g., $0.018 \mathrm{~mm}(1 \mathrm{ppm})$ ], which are typically used in commercial production, were sufficient to cause symptoms. Increased concentrations were associated with increased severity and higher leaf Fe concentrations. Based on these data, we suggest that occurrence of the disorder and its severity in commercial settings may depend on the Fe-chelate concentration in the liquid fertilizer program. Iron-chelate concentrations vary with $\mathrm{N}$ concentration of the liquid fertilizer and since $\mathrm{N}$ concentrations may vary significantly with each application, either deliberately or due to poor injector calibration, producers may be unaware of the actual $\mathrm{Fe}$-chelate concentrations being applied to the crop. Leachate Fe concentrations increased over time, thus the cumulative effects of repeated Fe-chelate applications are important factors in the occurrence of the disorder. Attempts to control this disorder by managing nutrient solution or medium $\mathrm{pH}$ are unlikely to be fully effective as Fe-DTPA remains fairly stable between $\mathrm{pH}$ 4-7 and fairly water-soluble $(>50 \%)$ in a high $\mathrm{pH}(7.25)$ peat-based medium several days after application.

\section{Literature Cited}

Albano, J.P. and M.C. Halbrooks. 1991. Relationship of bronze speckle of marigold to iron DTPA and Manganese EDTA in peat-based media. HortScience 26:99. (Abstr.)

Albano, J.P. and W.B. Miller. 1993. Iron distribution and the occurrence of a physiological disorder in marigold. HortScience 28:550. (Abstr.)

Allen, S.E., H.M. Grimshaw, and A.P. Rowland. 1986. Chemical analysis, p. 301. In: P.D. Moore and S.B. Chapman (eds.). Methods in plant ecology. 2nd ed. Blackwell Sci. Publ., Oxford.

Arnold, N. and M. Binns. 1987. Fe, Mn, and the grey effect in hydroponically cultured flue-cured tobacco. Plant Soil 101:39-43.

Berghage, R.D., D.M. Drauskopf, D.D. Warncke, and I. Widders. 1987. Micronutrient testing of plant growth media: Extractant identification and evaluation. Commun. Soil Sci. Plant Ann. 18:1089-1110.

Bienfait, H.F. 1988. Mechanisms in Fe-efficiency reactions of higher plants. J. Plant Nutr. 11(6-11):605-629.

Bienfait, H.F. and Van der Mark. 1983. Phytoferritin and its role in iron metabolism, p. 111-123. In: D.A. Robb and W.S. Pierpoint (eds.). Metals and micronutrients: Uptake and utilization by plants. Academic Press, New York.

Biernbaum, J.A, W.H. Carlson, C.A. Shoemaker, and R. Heins. 1988. Low $\mathrm{pH}$ causes iron and manganese toxicity. Greenhouse Grower 6(3): 92-93, 96-97.

Boxma, R. 1981. Effect of $\mathrm{pH}$ on the behavior of various iron chelates in sphagnum (moss) peat. Commun. Soil Sci. Plant Ann. 12(8):755-763.

Broschat, T.K. and H.M. Donselman. 1985. Extractable Mg, Fe, Mn, Zn, and $\mathrm{Cu}$ from a peat-based container medium amended with various micronutrient fertilizers. J. Amer. Soc. Hort. Sci. 110:196-200.

Carlson, W.H. 1988. The secret culprit: pH. Greenhouse Grower 6(1):1213.

Chaney, R.L. 1988. Metal speciation and interaction among elements affecting trace element transfer in agricultural and environmental foodchains, p. 219-260. In: J.R. Kramer and H.E.Allen (eds.). Metal speciation: Theory, analysis, and application. Lewis Publishers, Chelsea, Mich.

Foy, C.D., R.L. Chaney, and M.C. White. 1978. The physiology of metal toxicity in plants. Annu. Rev. Plant Physiol. 29:511-566.

Halbrooks, M.C. and J.P. Albano. 1990. Relationship of iron and manganese availability in peat-based media to the occurrence of a specific physiological disorder in Tagetes erecta. HortScience 25:109. (Abstr.) Handreck, K.A. 1989. Assessment of iron availability in soilless potting media. Commun. Soil Sci. Plant Ann. 20:1297-1320.

Hannam, R.J., and K. Ohki. 1988. Detection of manganese deficiency and toxicity in plants, p. 252. In: R.D. Graham, R.J. Hannam, and N.C. Uren 
(eds.). Manganese in soils and plants. Kluwer Academic, The Netherlands.

Lindsay, W.L. 1974. Role of chelation in micronutrient availability, p. 507-524. In: E.W. Carson (ed.). The plant root and its environment. Univ. of Va., Charlottesville.

Lindsay, W.L. 1979. Chemical equilibria in soils. Wiley, New York.

Markus, D.K., J.E. Steckel, and J.R. Trout. 1981. Micronutrient testing in artificial mix substrates. Acta Hort. 126:219-225.

Marschner, H., V. Romheld, and H. Ossenberg-Neuhas. 1982. Rapid method for measuring changes in $\mathrm{pH}$ and reducing process along roots of intact plants. Z. Pflatzenphysiology 105:407-416.

Mitchell, R.L. 1954. Trace elements in Scottish peats. Intl. Peat Symp. Section B3, Dublin.

Norvell, W.A. and W.L. Lindsay. 1969. Reactions of EDTA complexes of $\mathrm{Fe}, \mathrm{Zn}, \mathrm{Mn}$, and $\mathrm{Cu}$ with soils. Proc. Soil Sci. Soc. Amer. 33:86-91.

Romheld, V. and H. Marschner. 1983. Mechanism of iron uptake by peanut plants. I. FeIII reduction, chelate splitting, and release of phenolics. Plant Physiol. 71:949-954.

Somers, I.I. and J.W. Shive. 1942. The iron-manganese relation in plant metabolism. Plant Physiol. 17:582-602.

Thiel, E.C. 1987. Ferritin: Structure, gene regulation, and cellular func- tion in animals, plants, and microorganisms. Annu. Rev. Biochem. $56: 289-315$.

Tiffin, L.O., J.C. Brown, and R.W. Krauss. 1960. Differential absorption of metal chelate components by plant roots. Plant Physiol. 35:362-367.

U.S. Dept. of Agr. 1993. Floriculture crops 1992 summary. U.S. Dept. of Agr. N.A.S.S., Sp Cr 6-1(93). Wash., D.C.

van der Mark F., T. deLange, and H.F. Bienfait. 1981. The role of ferritin in developing primary bean leaves under various light conditions. Planta 153:338-342.

Verkleij, J.A. and H. Schat. 1990. Mechanisms of heavy metal tolerance in higher plants, p. 180-189. In: A.J. Shaw, (ed.). Heavy metal tolerance in plants: Evolutionary aspects. CRC Press, Boca Raton, Fla.

Vetanovetz, R.P. and J.F. Knauss. 1989. Iron toxicity: What you should know! Benchmarks 4(5):3-4. Grace, Cambridge, Mass.

Walsh, T. and T.A. Barry. 1958. The chemical composition of some Irish peats. Proc. Royal Irish Acad. 59B:305-328.

Warden, B.T. and H.M. Reisenauer. 1991. Manganese-iron interactions in plant-soil system. J. Plant Nutr. 14:7-30.

Welch, R.M. and T.A. LaRue. 1990. Physiological characteristics of Fe accumulation in the bronze mutant of Pisum sativum L., cv 'Sparkle' E107 (brz brz). Plant Physiol. 93:723-729. 